\title{
ANALYSIS OF SERVICE QUALITY FACTORS ON CUSTOMER SATISFACTION ON TAXI ONLINE IN MEDAN CITY
}

\author{
Raihanah Daulay ${ }^{1}$, Muhriza Al Rany ${ }^{2}$ \\ Faculty of Economics and Business, University of Muhammadiyah Sumatera Utara \\ raihanahdaulay@umsu.ac.id ${ }^{l}$
}

\begin{abstract}
Taxi is one of the most needed means of transportation today. This can be seen from the many emerging types of taxi transport both long-standing and has a name and now many emerging that is online transportation. The large number of taxi transport companies makes companies compete with other taxi service companies. Various ways are done to attract or retain consumers, including by providing quality services to maintain their customer satisfaction. This study aims to analyze the influence of variable Responsiveness, Physical Evidence and Credibility to customer satisfaction on Taxi Online in Medan City. Conducted survey method to 100 respondents. Data analysis techniques use multiple regression coefficient of correlation. The results of multiple regression coefficient of correlation show $Y$ $=5.614+0.424 X 1+0.124 X 2+0.338 X 3+0.341 X 4$. Partial hypothesis results show the variable responsiveness and credibility affect the customer satisfaction while the physical evidence variable does not influence the customer satisfaction. The simultaneous test results show that there is a significant influence of service quality on customer satisfaction on taxi online in Medan City.
\end{abstract}

Keywords: Responsibility, Physical Evidence, Credibility, Quality Factors and Customer Satisfaction

\section{INTRODUCTION}

Every company is required to recognize the market or consumers as possible in order to successfully compete in every business transportation is no exception. Competition is getting tighter as more and more producers are involved in fulfilling the needs and desires of consumers cause every company should put the orientation on the consumer as the main goal. This is because the consumer is a vital part of the existence of products on the market where the acceptance or rejection of a product.

Customer satisfaction is the ratio between perceived service and the predicted before service is purchased / consumed. If the perceived customer exceeds expectations, customers will feel satisfied, on the contrary if the perceived lower than expectations, customers are not satisfied. Many factors that can lead to a sense of satisfaction to customers include product quality, service quality, emotional, price and cost.

The development of transportation facilities, especially land transportation experienced a very rapid increase, both in terms of quality and quantity. In terms of quality can be seen from the improved service, the suitability of tariffs and facilities provided to consumers. In terms of quantity such as the increasing fleet of vehicles available to consumers so it will be comparable with the number of consumers who will use the transportation services. That means the transport service manufacturer must be sensitive to the existing reality of the need for transportation desired by consumers. Customer satisfaction is the ratio between perceived service and the predicted before service is purchased / consumed. If the perceived customer exceeds expectations, customers will feel satisfied, on the contrary if the perceived lower than expectations, customers are not satisfied. Many factors that can lead to a sense of satisfaction to customers include product quality, service quality, emotional, price and cost.

Consumers may experience different levels of satisfaction, if the performance of the product does not match expectations after consumed then the consumer will feel dissatisfied. But if the opposite happens, the product performance in accordance with expectations then consumers will feel satisfied that one day will consume the product again.

Taxi online is one type of taxi transportation which is now again rampant to operate in Medan City. In carrying out its activities, this company also has competition with other taxi companies that have been previously operating. To face the competition, one of the strategies used by the taxi as the producer of taxi transportation services is to always give maximum satisfaction for the taxi service 
users. Strategies undertaken by taxi such as by providing optimal service quality by providing existing facilities that are considered very influential in make a profit.

Companies engaged in transportation as a service provider must pay attention to the level of customer satisfaction after using the transport because the development of transportation services today is growing rapidly. Every company must be able to provide good services and facilities so that consumers are satisfied with what is received with the given value.

Quality of service will be felt by consumers if using a product or service goods. Quality of service received by customers from the use of taxi services is necessary because consumers assume that the taxi can provide the level of satisfaction for consumers. However, based on observations in the field it is known that taxis are often unwilling to accept passengers during busy times where there are frequent congestion, unsuitable facilities required by consumers, high prices during peak hours.

\section{Consumer Satisfaction}

Customer satisfaction has an important role for the company. Because as sophisticated or as good as the product produced by the company, if the consumer does not like it, either because it is too expensive or too complicated in its use, then the product is meaningless. In other cases consumers may be reluctant to buy certain brands because their products are poor quality, but they may have been disappointed in the service at the time or after purchase, or because the brand is only available in certain places, or maybe because the payment system is very rigid. If expectations can be fulfilled or exceeded then the customer will feel the satisfaction in him, but if these expectations are not met then there is dissatisfaction. According to Kotler (2000), that customer satisfaction is the level of one's feelings after comparing perceived performance (outcome) compared to expectations.

This phenomenon shows that to satisfy the consumer is not a simple problem but is a complex problem that is interrelated. Therefore, the strategy to satisfy consumers needs to be done in a planned and integrated. Satisfaction has become a key concept in marketing theory and practice. And is one of the essential goals for business activities.

Satisfaction is the feeling of pleasure or disappointment of someone who emerges after comparing the perception / impression to the performance (or outcome) of a project and its expectations. (Kotler 2004). Satisfaction is a function of perception / impression of performance and expectation. If the performance is below expectations, then the customer is not satisfied, and if the performance meets expectations, then the customer will feel satisfied. If performance exceeds expectations, the customer is very satisfied or happy.

Customer satisfaction by Anderson in Tjiptono (2006, pp. 348-349) contributes to a number of crucial aspects, such as customer loyalty, increased corporate reputation, reduced price elasticity, reduced future transaction costs and increased employee efficiency and productivity.

Satisfaction is seen as one of the dimensions of market performance. Improved customer satisfaction has the potential to lead to long-term and short-term sales growth, as well as market share as a result of repurchase (Tjiptono, 2007). Satisfaction is also seen as one of the best indicators for future earnings. Satisfaction is a function of perceptions of impressions of performance and expectations. If performance is below expectations, customers will be disappointed. When performance meets expectations, customers will be satisfied and when performance exceeds expectations, customers will be very satisfied and happy.

\section{Service Quality}

Service can be said to be a beneficial activity and loyalty offered for sale. This is because the purchase of a service often also involves attitudes and layout that complete it such as a comfortable room atmosphere, security facilities and so on.

According to Parasuraman, Berry and Zenthaml in Lupiyoadi (2008, p.181) Quality of service as to how far the difference between reality and customer service expectations they receive. According to Tjiptono (2000, p. 58) the meaning of service excellence is to serve customers satisfactorily, there are four main elements of speed, accuracy, hospitality and convenience.

According to Gronroos (in Ratminto and Winarsi, (2005, p2) "Service is an activity or a series of invisible (non-tangible) activities that occur as a result of the interaction between the consumer and the employee or other things caused by a service provider company intended to solve consumer / consumer problems ". 
An important role of service quality is to be able to serve customers satisfactorily, both with the skills and competencies possessed by employees (attitude, appearance, attention, action, responsibility, speed, accuracy, friendliness) or by maximizing supporting facilities (building, interior and exterior design and equipment / equipment) that can create comfort for customers. In other words, it can be said that the important role of excellent service lies in the ability of producers to provide optimal service to their customers by combining the capabilities of the staff and maximizing the supporting facilities.

\section{PURPOSE OF STUDY}

To analyze the influence of variable responsiveness, physical evidence and credibility to customer satisfaction on taxi online in medan city

\section{RESEARCH METHODOLOGY}

In this study the data used is primary data, the data obtained directly from the location of research in the form of data about each variable (Quality of Service, and Customer Satisfaction). Teknik used in data collection this study using questionnaires and observations.

The operational variables and definitions of this research are as follows:

1. Customer Satisfaction

Satisfaction is the evaluation of what is expected with the reality (performance) that customers perceive to the services that have been given.

2. Quality of Service

Quality of Service is the action from one party to another in fulfilling the needs and wishes of the other party in purchasing the product. Thus service in general is a pleasant feeling given to others accompanied by ease and fulfill all their needs. Quality of service consists of:

a. Responsiveness

Responsiveness, ie the desire of the company to help and provide services with a quick and responsive to the customer.

b. Physical evidence

Infrastructure means facilities of physical facilities, equipment owned, and other physical infrastructure facilities services.

c. Credibility

Credibility is the ability to perform services as promised immediately, accurately, and satisfactorily.

\begin{tabular}{|l|l|}
\hline Variable & Indicators \\
\hline 1. Customer & $\begin{array}{l}\text { 1. Customer satisfaction on knowledge, ability, courtesy and } \\
\text { trustworthiness }\end{array}$ \\
& $\begin{array}{l}\text { 2. Customer satisfaction on the info is good and clear } \\
\text { 3. Customer satisfaction for fast and accurate service }\end{array}$ \\
& 4. Customer satisfaction for attention and caring. \\
\hline Responsiveness $\left(\mathrm{X}_{1}\right)$ & $\begin{array}{l}\text { 1. Responsive to customer needs condition; } \\
\text { 2. Fast and accurate service. }\end{array}$ \\
\hline Physical evidence $\left(\mathrm{X}_{2}\right)$ & 1. Service supporting equipment; \\
& 2. Company location; \\
& 3. Driver's neatness and appearance; \\
& 4. Media information owned. \\
\hline Credibility $\left(\mathrm{X}_{3}\right)$ & 1. Compliance of service pledge provided to the customer; \\
& 2. Service compliance with rules; \\
& 3. Speed in providing services; \\
& 4. Ease and accuracy of administration. \\
\hline
\end{tabular}

Table 1. Oparationalization of Research Variables

Source: Linda Nur Susila (Journal of Rural and Development Volume 1 No. 1 Februari 2010). 


\section{Analysis Multiple Linear Regression}

This model of analysis is used to determine the effect of independent variables either together or partially to the dependent variable.

The regression equation used is as follows (Salvatore, 2005:173) :

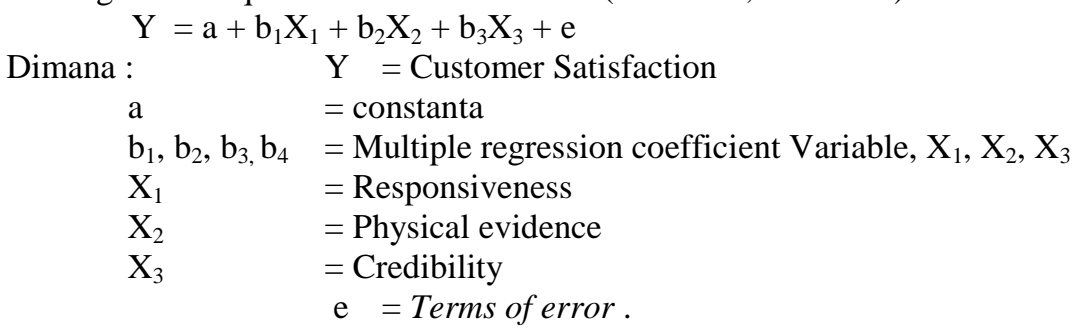

\section{Partial Significance Test (Test-t)}

Partial test (t test) aims to see the effect of independent variables namely Responsiveness, physical evidence and credibility to customer satisfaction. In this research the $\mathrm{t}$ count $<\mathrm{t}$ table, at the significance $(\alpha)=5 \%$.

\section{Simultaneous Significance Test (Test-t)}

The simultaneous test ( $F$ test) is used to determine the effect of jointly independent variables on the dependent variable. The test criterion of $\mathrm{F}$ count $>\mathrm{F}$ table, at a significant $(\alpha)=5 \%$.

\section{RESULTS AND DISCUSSION}

\section{Results Of Multiple Regression}

\begin{tabular}{|c|c|c|c|c|c|}
\hline \multirow[b]{2}{*}{ Model } & \multicolumn{2}{|c|}{$\begin{array}{l}\text { Unstandardized } \\
\text { Coefficients }\end{array}$} & \multirow{2}{*}{$\begin{array}{c}\begin{array}{c}\text { Standardized } \\
\text { Coefficients }\end{array} \\
\text { Beta }\end{array}$} & \multirow[b]{2}{*}{$\mathrm{t}$} & \multirow[b]{2}{*}{ Sig. } \\
\hline & $B$ & Std. Error & & & \\
\hline (Constant) & 5.614 & 2.085 & & 2.693 & .008 \\
\hline Responsiveness & .424 & .119 & .326 & 3.562 & .001 \\
\hline Physical evidence & .124 & .114 & .100 & 1.084 & .281 \\
\hline Credibility & .338 & .122 & .244 & 2.763 & .007 \\
\hline
\end{tabular}

a. Dependent Variable: Customer Satisfaction

Table 2

The Results Of Correlation Coefficient

The table above shows the multiple regression are:

$\mathrm{Y}=5.614+0.424 \mathrm{X} 1+0.124 \mathrm{X} 2+0.338 \mathrm{X} 3$

From the regression equation above, the variable responsiveness produce $\mathrm{b} 1=0,424$ which means that every variable responsiveness increases by $1 \%$ the customer satisfaction will rise of 0,424 assuming the other variables fixed and the influence of responsiveness towards customer satisfaction is significant.

Variable physical evidence yields b2 $=0,124$ which means that any increase in the variable physical evidence of 1 then customer satisfaction will rise of 0124 assuming the other variables fixed the power and influence of responsiveness to customer satisfaction is not significant.

Variable credibility produces $\mathrm{b} 3=0,338$ which means that every variable increases the credibility of 1 then customer satisfaction will rise of 0,338 assuming the other variables fixed and the influence of credibility towards customers ' satisfaction is significant. 


\section{Results of Partial Test (Test- t)}

The results of calculation of test-t can be seen in the table coefisien above:

1. The positive responsiveness of influential Variables and significantly to customer satisfaction.

2. Variable physical evidence does not affect customer satisfaction

3. The Variable is positive and significant effect of credibility towards customer satisfaction.

\section{Result of Simultaneous Test (Test- F)}

To know the variable quality of service together against variable customer satisfaction can be seen in the following table:

ANOVA $^{\mathrm{D}}$

\begin{tabular}{|l|r|r|r|c|c|}
\hline Model & Sum of Squares & df & Mean Square & $F$ & Sig. \\
\hline 1 Regression & 654.263 & 4 & 163.566 & 28.405 & $.000^{\mathrm{a}}$ \\
Residual & 547.047 & 95 & 5.758 & & \\
Total & 1201.310 & 99 & & & \\
\hline
\end{tabular}

a. Predictors: (Constant), Responsiveness, Credibility, Physical evidence

b. Dependent Variable: Customer Satisfaction

Table 3. Test- F

In the table above are known to value $\mathrm{F}$ calculate registration $(28.405>2.46)$ and the value of sig. probability $0.000<0.05$. Shows there is a significant influence on the quality of service to customer satisfaction on a taxi online in the city of Medan.

\section{Coefficient of Determination (R2)}

To see how much influence the quality of service to the customer satisfaction can be viewed from the value of the coefficient of determination in the following table:

\begin{tabular}{|c|c|c|c|c|}
\hline & & & & Model Summary \\
Model & $\mathrm{R}$ & $\mathrm{R}$ Square & Adjusted R Square & the Estimate \\
\hline 1 & $.738^{\mathrm{a}}$ & .545 & .525 & 2.400 \\
\hline
\end{tabular}

a. Predictors: (Constant), Responsiveness, Credibility, Physical evidence

b. Dependent Variable: Customer Satisfaction

Tabel IV-40 : Koefesien Determinasi

From the results of the above calculation note that $\mathrm{R}^{2}$ is $0.54554 .5 \%$ means of service quality affects the rest of the customers and the Papal $45.5 \%$ are influenced by factors other than this research. 


\section{DISCUSSION}

From the results of the above calculation note that $\mathrm{R}^{2}$ is 0.545 . This means that $54.5 \%$ service quality affects the rest of the customers and the Papal $45.5 \%$ are influenced by factors other than this research. Partial test results obtained from the variable service quality (responsiveness $\left(\mathrm{X}_{1}\right)$, physical evidence $\left(\mathrm{X}_{2}\right)$ and credibility $\left(\mathrm{X}_{3}\right)$ ) shows that the variable responsiveness has significant effects against variable customer satisfaction. Variable no physical evidence of significant influence towards customer satisfaction. Credibility of influential variables significantly to customer satisfaction on your taxi customers on line in the city of Medan. The results of this study in accordance with the theory that suggested Lenroy Setiawan $(2011$, p. 34) that the quality of services is a major factor that affects customer satisfaction.

Results from the simultaneous Trials retrieved variable service quality (responsiveness (X ${ }_{1}$ ), physical evidence $\left(X_{2}\right)$ and credibility $\left(X_{3}\right)$ ) that the variable quality of service have significant influence towards customer satisfaction variable on taxi customers on line at The City Of Medan. The results of this study in accordance with the theory of advanced Lupiyoadi $(2001$, p. 158) that the price and quality of service is important factors that trigger the onset of a satisfied customer. The value of the coefficient of determination R-Square value of Adjust is obtained is of 0525, then approximately $52.5 \%$ variable variable influenced by customer satisfaction service quality and the remaining $47.5 \%$ are affected by other variables not examined.

\section{CONCLUSION}

In simultaneous test showed a positive and influential service quality significantly to customer satisfaction on taxion line in the city of Medan. This shows the quality of the services provided have given satisfaction on service quality, consumers have an important role in determining the success of a product or service. If the company produce quality good service then consumers will feel satisfied with what they have come to expect, let alone customers have felt the service quality of products/services that directly.

On the partial test, variable physical evidence shows the results was not significant, for it is the service provider should be able to improve a better facility, which provides a means of meeting the needs of consumers so that customer satisfaction can be are met and the transport service users online.

\section{REFERENCES}

Imam Ghozali. 2005. Aplikasi Analisis Multivariate Dengan Program SPSS, Universitas Diponegoro, Semarang.

Kotler, Philip. 2000. Manajemen Pemasaran Edisi Milenium. Jakarta: Prenhallindo.

Kotler, Philip. 2002. Manajemen Pemasaran (Edisi Milenium). Jakarta: PT Prenhalindo.

Kotler, Philip. 2004 Manajemen Pemasaran. Edisi Milenium Satu. Jakarta: PT. Indeks kelompok Gramedia,

Lupiyoadi, Rambat. 2001. Manajemen Pemasaran Jasa Teori dan Praktik. Jakarta: Salemba Empat,

Rambat Lupiyoadi dan A.Hamdani. 2006. Manajemen Pemasaran Jasa. Jakarta : Salemba Empat.

Ratminto., Winarsih, Atik Septi. 2010. Manajemen Pelayanan: Pengembangan Model Konseptual, Penerapan Citizen's Charter dan Standar Pelayanan Minimal. Yogyakarta: Pustaka Pelajar.

Setiawan supriadi. 2011. Loyalitas Pelanggan Jasa.IPB Press:Bogor.

Sugiyono. 2006. Statistika Untuk Penelitian. Bandung: Alfabeta.

Sugiyono. 2008. Statistika Untuk Penelitian. Bandung: Alfabeta.

Tjiptono \& Fandy. 2000. Manajemen Jasa. Yogyakarta: Penerbit Andi.

Tjiptono \& Fandy. 2004. Manajemen Jasa. ANDI. Yogyakarta.

Tjiptono, Fandy dan Gregorius Chandra. 2005. Service, Quality and Satisfaction,

Edisi Pertama, Penerbit Andi, Yogyakarta.

Tjiptono. 2006. Manajemen Jasa. Edisi II, Yogyakarta: Andi Offset.

Tjiptono, Fandy. 2007. Pemasaran Jasa. Malang: Bayumedia Publising.

Linda Nur Susila. 2010. Analisis pengaruh kualitas pelayanan kantor kelurahan terhadap kepuasan masyarakat kelurahan jagalan kecamatan jebres kota surakarta. Journal Of Rural And Development. Volume 1. 